\title{
Bescherming tegen niet geïnviteerde overnames en ongewenst aandeelhoudersactivisme
}

Citation for published version (APA):

Steins Bisschop, B. T. M. (2008). Bescherming tegen niet geïnviteerde overnames en ongewenst aandeelhoudersactivisme. Uitgeverij Paris. https://doi.org/10.26481/spe.20080522bsb

Document status and date:

Published: 22/05/2008

DOI:

10.26481/spe.20080522bsb

Document Version:

Publisher's PDF, also known as Version of record

\section{Please check the document version of this publication:}

- A submitted manuscript is the version of the article upon submission and before peer-review. There can be important differences between the submitted version and the official published version of record.

People interested in the research are advised to contact the author for the final version of the publication, or visit the DOI to the publisher's website.

- The final author version and the galley proof are versions of the publication after peer review.

- The final published version features the final layout of the paper including the volume, issue and page numbers.

Link to publication

\footnotetext{
General rights rights.

- You may freely distribute the URL identifying the publication in the public portal. please follow below link for the End User Agreement:

www.umlib.nl/taverne-license

Take down policy

If you believe that this document breaches copyright please contact us at:

repository@maastrichtuniversity.nl

providing details and we will investigate your claim.
}

Copyright and moral rights for the publications made accessible in the public portal are retained by the authors and/or other copyright owners and it is a condition of accessing publications that users recognise and abide by the legal requirements associated with these

- Users may download and print one copy of any publication from the public portal for the purpose of private study or research.

- You may not further distribute the material or use it for any profit-making activity or commercial gain

If the publication is distributed under the terms of Article $25 \mathrm{fa}$ of the Dutch Copyright Act, indicated by the "Taverne" license above, 


\section{Bas Steins Bisschop}

Bescherming tegen niet geïnviteerde overnames en ongewenst aandeelhoudersactivisme
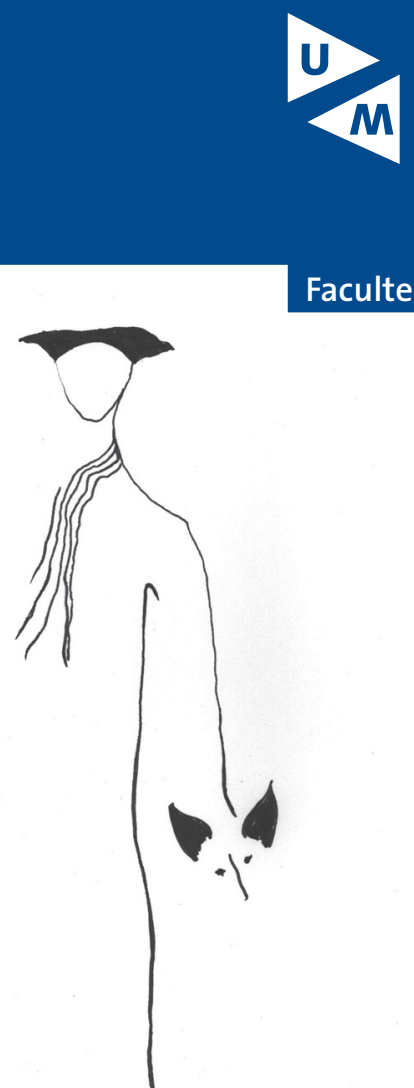

Bescherming tegen niet geïnviteerde overnames en ongewenst aandeelhoudersactivisme 


\section{Colofon}

Ontwerp en print: Océ Business Services, Maastricht

ISBN: $\quad 978-90-5681-285-0$

NUR: $\quad 827$

Alle rechten voorbehouden. Niets uit deze uitgave mag worden verveelvoudigd, opgeslagen in een geautomtiseerd gegevensbestand of openbaar gemaakt worden, zonder voorafgaande schriftelijke toestemming van de auteur of uitgever. 


\section{Bas Steins Bisschop}

\section{Bescherming tegen niet geïnviteerde overnames en ongewenst aandeelhoudersactivisme}

Een politiek correcte en bedrijfsmatig effectieve benadering

\section{Rede}

uitgesproken bij de aanvaarding van het ambt van bijzonder hoogleraar ondernemingsrecht en corporate governance in de juridische faculteit van de Universiteit Maastricht op donderdag 22 mei 2008 

HoOFDSTUK 1

INLEIDING

BESCHERMINGSMAATREGELEN IN

PERSPECTIEF

Niets is zo praktisch als een goede theorie. ${ }^{1}$ De combinatie van theorie en praktijk vormt de basis van mijn huidig bestaan. Als advocaat zie ik hoe het gaat en als academicus zie ik hoe het moet. Ik raak wel eens in de knoop door de verleiding: "als het niet gaat zoals het moet, moet het maar zoals het gaat". Beschermingsmaatregelen zijn zo'n verwarrend verschijnsel. Mag het niet en moet het wel? De stemming in corporate governance land is tegen bescherming, maar de behoefte in de praktijk lijkt toe te nemen. In deze oratie zal ik de balans aangaande beschermingsmaatregelen opmaken, de knelpunten in de beschermingspraktijk signaleren en een oplossing aandragen. Die oplossing past in het huidige politieke klimaat, maar zou tegelijkertijd tegemoet kunnen komen aan de wensen en verlangens van het bedrijfsleven.

De aandeelhouders verschaffen kapitaal aan de vennootschap en delegeren het bestuur om de scheiding tussen financieren en ondernemen gestalte te geven. De kapitaalverschaffing en delegatie van bestuur geschieden niet onvoorwaardelijk. Zo behouden de aandeelhouders een zekere controle over de aanwending van hun kapitaal. Het belangrijkste controlerecht is het recht om de bestuurders aan te stellen en te ontslaan, wanneer de bestuurders in de ogen van de aandeelhouders onvoldoende opkomen voor hun belangen. Ondanks de juridische beperkingen impliceert dit recht feitelijk dat aandeelhouders ruime instructies kunnen geven aan het bestuur. Het tweede belangrijke controlerecht van aandeelhouders betreft de financiële gang van zaken. Het is aan de aandeelhouders om de jaarrekening waaruit het resultaat blijkt, vast te stellen. Het

Dit is de enige voetnoot in deze verkorte versie van de oratie. De volledige tekst is verschenen in de handelseditie door Uitgeverij Paris, Zutphen, ISBN 978-90-77320-60-0; NUR 827 
derde recht van aandeelhouders betreft alle zaken die met het aandelenkapitaal te maken hebben. De aandeelhoudersrechten worden immers toegekend aan de hand van het nominale bedrag dat door de individuele aandeelhouders wordt gehouden, zodat de aandeelhouders belang hebben bij controle over de belangrijkste besluiten aangaande het kapitaal zoals de emissiekoers bij de uitgifte van nieuwe aandelen, de inkoop van uitgegeven aandelen en het intrekken ervan, en het wijzigen van het nominale bedrag van het aandeel. Tot slot dient bedacht te worden dat aandeelhouders zich in een kwetsbare positie bevinden omdat zij het kapitaal ter beschikking hebben gesteld, maar in beginsel pas op een langere termijn daarna genieten van de eventuele voordelen van hun kapitaalstorting. Dat proces van wachten moet zich afspelen in een gereguleerde omgeving. Eén van de belangrijkste vormen van regulering is het vormgeven van de statuten van de vennootschap. Het vaststellen en nadien wijzigen van de in de statuten vervatte spelregels dient dan ook een exclusieve bevoegdheid van de aandeelhouders te zijn.

Het is naar mijn oordeel noch in de continentaal-Europese noch in de Angelsaksische traditie juist om te stellen dat de aandeelhouders de eigenaren van de onderneming of van de vennootschap zijn. Aandeelhouders zijn uitsluitend eigenaar van het aandeel en de rechtspersoon is eigenaar van de onderneming.

Deze algemene duiding van de ondernemingsorganisatie geeft een goede context voor begrip van beschermingsmaatregelen. Deze worden steeds gehanteerd in de relatie tussen enerzijds het bestuur van de onderneming, dat zich verzet tegen machtsuitoefening op aandeelhoudersniveau door degene tegen wie de beschermingsmaatregelen zich richten, en anderzijds degene die dergelijke macht juist wil uitoefenen in de hoedanigheid van activistische aandeelhouder of van bieder op alle aandelen teneinde door middel van een openbaar bod de meerderheid van de zeggenschap in de aandeelhoudersvergadering te verkrijgen. 
Beschermingsmaatregelen beogen kort gezegd de uitoefening van één of meer van de vier kernrechten van het aandeelhouderschap te frustreren.

Beschermingsmaatregelen worden primair ingezet bij overnames waaromtrent geen overeenstemming bestaat tussen het bestuur van de doelvennootschap en de mogelijke bieder op de aandelen. Beschermingsmaatregelen worden ook ingezet in situaties waarin de aandeelhoudersvergadering wordt gedomineerd door een 'toevallige meerderheid' in de vergadering, zonder dat deze vergadermeerderheid evenwel de meerderheid van het kapitaal vertegenwoordigt. Tot voor kort leek de rol van beschermingsmaatregelen beperkt tot deze twee functies, maar sinds het in de afgelopen periode opgekomen verschijnsel van 'aandeelhoudersactivisme' moet een derde mogelijke rol van beschermingsmaatregelen worden onderkend, namelijk het kunnen fungeren als middel tegen machtsuitoefening door activistische aandeelhouders.

Het hebben en inzetten van beschermingsmaatregelen was voor Nederlandse beursfondsen tot voor kort staande praktijk. Daarin is een kentering gekomen, die ik later zal bespreken.

Beschermingsmaatregelen beogen de zeggensmacht die anders aan de kapitaalverschaffers van de vennootschap zou toekomen, te frustreren. Dat geschiedt in de regel door statutaire bepalingen die de macht van de aandeelhoudersvergadering beperken of de samenstelling ervan wijzigen. Deze in de Nederlandse praktijk gehanteerde vorm van bescherming wordt ook wel aangeduid als 'technische' bescherming. 
HOOFDSTUK 2

BESCHERMING EN CORPORATE GOVERNANCE

Tot ongeveer het begin van de jaren negentig in de vorige eeuw waren vrijwel alle beursfondsen beschermd door middel van enige vorm van beschermingsmaatregelen. De uitzondering op deze regel werd gevormd door vennootschappen die geen bescherming nodig hadden omdat de aandelen in vaste handen verkeerden, zoals bijvoorbeeld bij Heineken het geval was. Daar hanteerde de familie een piramidestructuur, waarbij de familie de kleinst denkbare meerderheid in Heineken Holding hield, en de overige aandelen in handen van het beleggend publiek waren, en waarbij Heineken Holding de kleinst denkbare meerderheid in Heineken International hield.

De kentering is gekomen doordat in de ogen van velen de positie van 'de factor kapitaal' in de verdrukking was geraakt, terwijl de positie van 'de factor arbeid' door wetgeving en jurisprudentie sedert de zestiger jaren aanzienlijk was versterkt.

In 1991 heb ik aandacht gevraagd voor de mogelijke beperkte houdbaarheid van beschermingsmaatregelen, door - kort samengevat - te bepleiten dat er een omslagpunt bestaat waarna het inroepen van beschermingsmaatregelen die op zich geldig zijn, niettemin spanning kan opleveren met de vennootschappelijke orde. Een dergelijke spanning kan ertoe leiden dat beschermingsmaatregelen niet langer houdbaar zijn, hetgeen betekent dat de zeggenschapsaanspraken op grond van de beschermingsmaatregelen genegeerd dienen te worden en de zeggenschapsaanspraken van de meerderheid van de kapitaalverschaffers dienen te prevaleren.

In 1991 was daarna een vergelijkbaar geluid te vernemen op het congres ter gelegenheid van het 25-jarig bestaan van het Van der Heijden Instituut. De bankier en oud-minister Ruding betoogde dat vanuit politiek en financieel-economisch oogpunt het ongebreideld beschermen van beursvennootschappen tegen 
vijandige overnames, of tegen aandeelhoudersinvloed in het algemeen, niet passend was en dat beursfondsen rekening dienden te houden met de mogelijkheid van de beperkte houdbaarheid van hun beschermingsmaatregelen.

In diezelfde periode twijfelde ook de bedrijfsjurist van Unilever en voormalig hoogleraar Honée aan de mogelijkheid van onbegrensd gebruik van beschermingsmaatregelen.

Vervolgens besloot ook de wetgever zich aan te sluiten bij het verzet tegen de praktijk van bescherming. In 1997 werd het wetsvoorstel inzake beschermingsmaatregelen ingediend. Het voorstel werd geïntroduceerd met de aankondiging: 'grootaandeelhouder kan beschermingsconstructies doorbreken'. Volgens de memorie van toelichting bij het wetsvoorstel kunnen belangrijke wijzigingen in de samenstelling van de aandeelhoudersvergadering door het bestuur en de commissarissen niet langdurig worden genegeerd. Het wetsvoorstel houdt een erkenning in van de principiële aanspraak van de aandeelhouders (en certificaathouders) op zeggenschap die proportioneel is met het door hen verschafte kapitaal. Vanwege de implementatie van de Dertiende Richtlijn is verdere parlementaire behandeling van dit wetsvoorstel achterwege gebleven en is het voorstel ingetrokken.

Het gebruik van beschermingsmaatregelen is aanzienlijk teruggedrongen. De meeste beursfondsen hanteren nog steeds beschermingsmaatregelen, maar de cumulatie van maatregelen is beperkt en het belangrijkste middel lijkt thans gevonden te worden in de mogelijkheid tot uitgifte van preferente beschermingsaandelen.

Op de vraag of beursfondsen op goede en verantwoorde gronden kunnen vertrouwen op de kracht van bescherming door preferente beschermingsaandelen, zal ik hierna terugkomen in hoofdstuk 5 .

De Nederlandse corporate governance discussie, de harmonisatie van het Europese vennootschapsrecht en met name de 
Dertiende Richtlijn, de commissie-Peters die in juni 1997 het rapport met de Veertig Aanbevelingen presenteerde, de Nederlandse corporate governance code (hierna: de Code) uit 2003, uitspraken van de Ondernemingskamer en de toevoeging van het vijfde lid aan art. 2:391 BW hebben geleid tot een sterk verminderd vertrouwen van beursfondsen op de beschermende werking van de cumulatie van beschermingsmaatregelen. Uit een rapport van de Universiteit van Tilburg en de Erasmus Universiteit Rotterdam in opdracht van de SER blijkt dat het gebruik van certificering als beschermingsmaatregel sterk is teruggelopen en dat men thans voornamelijk vertrouwen stelt in de werking van preferente beschermingsaandelen.

Bescherming werd getest in rechterlijke uitspraken.

In de Gucci-zaak bepaalde de Ondernemingskamer dat het de doelvennootschap in beginsel vrij staat een beleid te voeren dat erop is gericht zich te beschermen tegen een overname. Het lijkt erop dat in deze zaak de zogenoemde Unocal-test werd toegepast. Deze test bepaalt dat beschermingsmaatregelen alleen kunnen worden gehanteerd wanneer het bestuur een bedreiging van het vennootschappelijk belang heeft kunnen vaststellen waartegen beschermingsmaatregelen een proportionele reactie vormen. In de $H B G$-zaak speelde de vraag naar de beleidsvrijheid van het bestuur en het recht van de aandeelhoudersvergadering om ter zake van belangrijke ondernemingsbesluiten geconsulteerd of anderszins betrokken te worden. Bij het beoordelen van de geldigheid en houdbaarheid van beschermingsmaatregelen draait het eveneens om de machtsverdeling tussen bestuur en aandeelhouders.

In de Rodamco North America-zaak bepaalde de Hoge Raad dat bescherming alleen gerechtvaardigd is indien deze een 'adequate en proportionele reactie op het dreigende gevaar van een ongewenste overname' vormt. De Hoge Raad laat daarbij veel ruimte aan het bestuur, maar geeft tevens aan dat deze ruimte ook moet worden besteed aan onderling overleg en dat een maatregel voor onbepaalde tijd niet gerechtvaardigd is. 
In deze opsomming van rechterlijke uitspraken horen ook de uitspraken inzake Stork en $A B N$ Amro thuis. In het volgende hoofdstuk over activistische aandeelhouders worden deze uitspraken behandeld.

Bij de schets van de Nederlandse beschermingspraktijk heb ik het loyaliteitsdividend dat DSM voorstelde aan haar lange termijn aandeelhouders uit te keren buiten bespreking gelaten. Het voorgestelde loyaliteitsdividend heeft immers geen effect dat gelijkt op het effect van beschermingsmaatregelen. Toch hebben de rechterlijke uitspraken in deze zaak betekenis voor het denken over de geldigheid en houdbaarheid van beschermingsmaatregelen. Aan deze uitspraak kan extra gewicht worden toegekend omdat deze tot stand is gekomen na een betrekkelijk uitzonderlijke interventie van de advocaat-generaal die tegen de uitspraak van de Ondernemingskamer cassatieberoep in het belang der wet heeft ingesteld. De door de Hoge Raad gecorrigeerde uitspraak van de Ondernemingskamer leert dat het toekennen van privileges aan aandeelhouders die zich op lange termijn wensen te binden aan de vennootschap, geen ongeoorloofde inbreuk op het gelijkheidsbeginsel van art. 2:92 BW oplevert. Deze sanctionering door de Hoge Raad van de lange termijn strategie van de vennootschap gericht op het aan de vennootschap binden van loyale aandeelhouders is een aanwijzing voor het bestuur die ook relevant kan zijn bij het beoordelen van bestuurshandelen ter afwering van aandeelhoudersinitiatieven welke primair op korte termijn belangen zijn gericht. In de navolgende hoofdstukken zal ik voorbeelden geven van dergelijke aandeelhoudersinterventies die zich hebben afgespeeld vóór de datum van de DSMuitspraak. 
De ratio van een beursnotering is dat de onderneming ondernemingskapitaal verkrijgt van investerende aandeelhouders, die geen ondernemingsrisico wensen te lopen, maar wel willen profiteren van de successen van het bestuur, aan welk orgaan de aandeelhouders het ondernemen hebben gedelegeerd. Hoe groter het vertrouwen van investeerders in de kwaliteiten van het ondernemende bestuur, hoe gemakkelijker het aantrekken van vermogen van aandeelhouders. Hoe meer vermogen, hoe meer kans op ondernemingssucces. De terbeschikkingstelling van vermogen geschiedt niet zonder meer, maar onder de controlerende werking van bepaalde essentiële aandeelhoudersrechten, zoals de rechten die in onderdeel 1.1 zijn besproken. In het verleden werd van die aandeelhoudersrechten summier gebruik gemaakt en rekende men veeleer op de $W$ all Street Rule, het stemmen met de voeten. Dit houdt in dat aandeelhouders die niet tevreden waren over het ondernemingsbeleid dat lieten blijken door hun aandelen te verkopen. Als gevolg daarvan ontstaat prijsdruk op de aandelen en dit effect zou voldoende disciplinerend werken op het ondernemingsbestuur. Nog steeds wordt van dit mechanisme gebruik gemaakt, ook om de kosten die verbonden zijn aan het uitoefenen van stemrecht te vermijden. De grote investeerders zijn vaak vanwege hun nationaal en internationaal gespreide beleggingen welhaast gedwongen gebruik te maken van de liquiditeit van de aandelenmarkt.

Deze schets van het 'stemmen met de voeten' is een korte samenvatting van de traditionele functie van financiering van ondernemingen door middel van aandelenkapitaal en van de traditionele positie van aandeelhoudersrechten in dat verband. Maar in de huidige tijd moet die samenvatting worden aangevuld met de constatering dat aandeelhouders in toenemende mate gebruik maken van hun aandeelhoudersrechten. Deze rechten worden niet meer alleen gebruikt om gedane investeringen te 
monitoren, maar ook om andere doelstellingen te bereiken. Bovendien kunnen aandelen worden ingezet als derivaten, waarbij niet zozeer de onderliggende waarde van de onderneming centraal staat, maar wel bijvoorbeeld de waarde van de valuta waarin de aandelen zijn genoteerd. Aandelen kunnen ook worden uitgeleend aan partijen die niet geïnteresseerd zijn in de kapitaalaspecten van het aandeel, maar wel in de zeggenschapsrechten die daaraan zijn verbonden. Het lenen van aandelen kan ook dienen om het zogenoemde 'short gaan' mogelijk te maken: aandelen die men niet bezit, verkopen in de speculatieve verwachting dat de koers zal dalen. De verkoper voldoet aan de leveringsplicht door aan de koper aandelen te leveren die hij geleend heeft. Aan de uitlener levert hij aandelen terug door op dat moment tegen een lagere koers op de aandelenmarkt in te kopen. Aandelen kunnen ook speculatief worden ingezet om de onderneming te dwingen tot bepaalde strategische besluiten, die niet zozeer in het belang van de onderneming zijn, maar vooral strekken tot financieel voordeel van de speculerende aandeelhouder. De zeggensmacht verbonden aan het aandelenbezit kan worden aangewend om de onderneming te dwingen tot een reorganisatie van haar financiering, zodanig dat de aandeelhouder financiële voordelen geniet ten laste van de vennootschap die opgezadeld wordt met een schuldenlast.

In de geschreven, uitgebreider, versie van deze oratie heb ik enige voorbeelden geschetst van recente praktijkvoorbeelden. Daaruit blijken de volgende bevindingen:

Bij de overnamepoging van de London Stock Exchange speelde het sterke vermoeden dat de hedge funds door posities in te nemen, als investeerder in de London Stock Exchange en tevens als investeerder in de Deutsche Börse, het overnameproces hebben gemanipuleerd met het oogmerk eerst koerswinst te realiseren op grond van de verwachting dat de overname tot stand zou komen en vervolgens koerswinst te realiseren speculerend op het niet 
doorgaan van de transactie.

Bij de participatie door Apax in PCM en het daarop volgende vertrek van Apax als investeerder moet worden geconstateerd dat de vermogenspositie van PCM ernstig is verslechterd en dat de financiële voordelen die Apax heeft behaald, met name door uitkeringen uit middelen van PCM, aanzienlijk zijn geweest. De strijd die VNU heeft geleverd met de activistische aandeelhouders leert in ieder geval dat het uitgangspunt van bestuursautonomie op strategisch terrein op zijn minst genuanceerd moet worden, ondanks de bevestiging van de autonomie in recente rechterlijke uitspraken.

Een vergelijkbare conclusie dringt zich op wanneer de uitslag van de strijd tussen Stork en de activistische bedge funds wordt bekeken. In deze zaak bleken de aandeelhouders uiteindelijk ook op strategisch terrein, in ieder geval feitelijk en beoordeeld aan de hand van de resultaten, het voor het zeggen te hebben gehad.

De overname van $A B N$ Amro is geschied tegen de wens van het bestuur van de bank in en naar aanleiding van krachtig en activistisch aandringen door het hedge fund TCI. In de praktijk wordt nu de vraag gesteld of de Nederlandse economie is gediend met deze transactie en of de verschillende bij het proces betrokkenen, waaronder de Nederlandsche Bank, de Minister van Financiën en de Minister-president, juist hebben gehandeld.

Hoewel het op dit moment te vroeg is om een beoordeling van de nieuw ontstane situatie te geven, kan wel worden gesteld dat de zeer snelle gang van zaken vanaf 20 februari 2007 tot het moment waarop vrijwel zeker werd dat de overname door het Consortium doorgang zou vinden, heeft geleid tot verstrekkende gevolgen voor alle bij de ABN Amro direct betrokken, maar ook voor de indirect bij de bank betrokkenen, zoals klanten maar ook de regionale omgeving en de nationale economische belangen. Ik verwacht dat toekomstige analyses van de casus op zijn minst zullen wijzen op schending van sommige van die belangen en op de conclusie dat ook bij afweging van overige belangen, de transactie beter onder andere of gewijzigde voorwaarden tot 
stand had behoren te komen. In dit verband verwacht ik tevens dat door sommigen zal worden gesteld dat het besluit van ABN Amro om vooruitlopend op de invoering van art. 2:359b BW haar beschermingswal af te breken, kritisch zal worden bekeken.

\section{...waarom kwamen activistische aandeelhouders naar Nederland?}

De balans opmakend kan worden gezegd dat de houdbaarheid van beschermingsmaatregelen breed betwijfeld wordt, dat bescherming slechts kan worden ingezet om beperkte doelen te bereiken en dat de geldigheid en houdbaarheid van de enige beschermingsmaatregel die nog vrij algemeen wordt gehanteerd, preferente beschermingsaandelen, op juridische gronden betwistbaar is. Op dit laatste zal ik hierna verder ingaan. Deze analyse zou kunnen betekenen dat beschermen in Nederland geen zin heeft en dat niet geïnviteerde bieders en activistische aandeelhouders vrij spel hebben. Een van de gevolgen van een vrije overnamemarkt zou moeten zijn dat aandeelhouders ook buiten het overnamespel hun invloed moeten kunnen doen gelden. Daarmee is Nederland toegankelijker geworden voor buitenlandse beleggingen. De vraag is of Nederland hiermee in een uitzonderingspositie is gekomen. Het antwoord daarop moet positief luiden omdat vergelijkbare corporate governance bewegingen weliswaar zichtbaar zijn in andere EU-lidstaten, maar dat deze gepaard gaan met wezenlijk andere marktverschijnselen die het effect van de corporate governance ontwikkelingen lijken te verwateren.

De activiteiten van hedge funds kunnen positief geduid worden wanneer hun activiteiten neerkomen op arbitrage tussen de markt en slecht presterende ondernemingen. Zij kunnen negatief worden geduid wanneer zij een korte termijn belang nemen met als oogmerk zodanige inkomsten uit de vennootschap te verkrijgen dat het rendement voor de hedge funds aanzienlijk is, ook wanneer de continuiteit van de onderneming daardoor in gevaar zou komen. 
Bij het bespreken van de activiteiten van bedge funds dient bedacht te worden dat slechts een gering percentage van deze beleggers zich 'activistisch' opstelt. Niettemin roept het bijzonder grote vermogen onder hun beheer, de schatting is dat het gaat om ongeveer $€ 1.200$ miljard wereldwijd, niet zelden het beeld op dat zij agressieve en speculatieve methoden hanteren, onverantwoorde risico's nemen, en in hun jacht op winst regelmatig voor oververhitting van de markt zorgen, in het algemeen of met betrekking tot een specifiek fonds.

De conclusie uit dit alles is niet duidelijk. Er bestaan geen gronden om bedge funds als investeerders te weren. Niettemin leren de hiervoor beschreven praktijkgevallen en opvattingen dat het optreden van de bedge funds kan leiden tot situaties die door een aantal bij de vennootschap betrokken belanghebbenden als onwenselijk kunnen en mogen worden gekenschetst.

Door het lenen van aandelen kunnen activistische aandeelhouders een zeggenschapspositie opbouwen zonder een corresponderend economisch belang. De activistische aandeelhouder kan op die manier koerswinst realiseren door te speculeren op een oplopende koers van de gekochte aandelen in de overnamekandidaat en tevens op een neergaande koers van de (geleende) aandelen in de bieder, daarbij gebruik makend van het stemrecht van de aandelen in bieder en overnamekandidaat om de gewenste strategische bewegingen te beïnvloeden.

Het opleggen van een meldingsplicht van intenties zal geen oplossing voor het onzekerheidsprobleem bieden. De discussie over die meldingsplicht levert naar mijn oordeel wel een aanknopingspunt op in de discussie over beschermingsmaatregelen. Wanneer de intenties van een belangrijke aandeelhouder onduidelijk zijn en het bestuur van een vennootschap redenen heeft om aan te nemen dat er sprake zal zijn van aandeelhoudersactivisme of van een niet geïnviteerde overname, welke acties de continuiteit van de vennootschap of 
het bestuursbeleid kunnen bedreigen, kan dit aanleiding vormen om beschermingsmaatregelen te activeren, tenminste voor de periode dat die onduidelijkheid bestaat.

Naar mijn oordeel dient in dat verband doorslaggevende betekenis te worden toegekend aan het begrip 'vennootschappelijk belang'. Eerder duidde ik de term aan als een 'vector': een grootheid of aanduiding welke niet alleen een getalwaarde maar ook een richting heeft. Het vennootschappelijk belang impliceert immers niet alleen deelbelangen, zonder evenwel een optelling van die belangen te zijn, maar is ook een leidraad voor de vennootschap en haar organen bij het verwezenlijken van het vennootschappelijk doel.

Bij het beoordelen van de vrijheid van het bestuur bij zijn verzet tegen activistische aandeelhouders moet rekening worden gehouden met de fundamentele uitgangspunten van de vennootschappelijke organisatie, namelijk enerzijds dat het ondernemen door de aandeelhoudersvergadering is gedelegeerd aan het bestuur en anderzijds dat de kapitaalverschaffer in beginsel zeggenschap heeft evenredig aan de nominale waarde van het door hem ingelegde kapitaal. Beschermingsmaatregelen tasten nu juist die zeggenschap aan, en op het bestuur rust steeds zwaarder de verantwoordingsplicht om het hanteren ervan te rechtvaardigen.

De conclusie uit dit alles is dat nog veel onduidelijkheid bestaat over de ontwikkelingen in de markt en de juridische mogelijkheden om op te komen tegen actuele of dreigende inbreuken op het vennootschappelijk belang, hoe lastig het ook is om een concrete invulling aan dit laatste begrip te geven. 
HOOFDSTUK 4

OVERIGE RELEVANTE

ONTWIKKELINGEN IN DE MARKT

De constitutionalisering van het privaatrecht is ook herkenbaar in het vennootschapsrecht. Als voorbeeld noem ik de gelijkheidsgedachte die tot uitdrukking komt in art. 2:92 lid 2 BW. Afwijking daarvan kan slechts geschieden wanneer sprake is van een redelijke en objectieve rechtvaardiging, welke term weer wordt verduidelijkt door verwijzing naar de jurisprudentie van het Europees Hof voor de Rechten van de Mens.

Voor zover mij bekend hebben ondernemingen bij machtsuitoefening door activistische aandeelhouders of bij niet geïnviteerde bieders geen beroep gedaan op 'mensenrechten'. Rechtspersonen kunnen aanspraak maken op persoonlijke mensenrechten. Deze constatering is relevant ter aanvulling, of nadere kleuring, van de hiervoor besproken ondernemingsrechtelijke middelen, en met name artt. 8 en 9 van Boek 2 BW.

Deze artikelen werden door de Hoge Raad beoordeeld in de ABN Amro-zaak. De verwijzing naar de rechtszekerheid, gevolgd door een verwijzing naar de slagvaardigheid waarover het bestuur aangaande strategische zaken dient te beschikken, vormden een belangrijke basis voor het oordeel van de Hoge Raad dat de redelijkheid en billijkheid niet meebrachten dat aan de aandeelhoudersvergadering in dit geval een goedkeuringsrecht diende te worden toegekend.

Stel nu dat in de $A B N$ Amro-casus sprake zou zijn geweest van 'PCM-achtige' toestanden, en stel vervolgens dat op goede gronden zou kunnen worden betoogd dat inbreuk dreigde op fundamentele rechten van de vennootschap, dan wel van bij de vennootschap betrokken stakeholders, dan zou het wellicht pleitbaar zijn om te redeneren dat het rechtsonzekerheidsargument, althans voor zover gebaseerd op 'ongeschreven recht', geen geldigheid meer heeft vanwege de 
constitutionalisering van het privaatrecht, c.q. het vennootschapsrecht. Dit is voorzichtig geformuleerd. Daarmee wil ik aangeven dat ik niet verwacht dat argumenten ontleend aan fundamentele rechten van de mens zullen leiden tot directe legitimering van beschermingsmaatregelen. Naar mijn oordeel behoren deze argumenten echter wel tot het juridisch instrumentarium bij de beoordeling van de geldigheid en houdbaarheid van beschermingsmaatregelen.

De BRIC-landen en de oliestaten beschikken over zeer grote financiële reserves die op overheidsniveau worden beheerd en besteed. Sommige landen hebben afzonderlijke instellingen in het leven geroepen om deze reserves te besteden. Het gaat om 'Sovereign Wealth Funds' ofwel staatsfondsen. Deze overheidsinstellingen worden mede vanuit politieke overwegingen bestuurd en kunnen daarom ook politieke doelstellingen nastreven. In de Verenigde Staten bestaat toenemende zorg over de belangen die door deze staatsinstellingen worden genomen in bijvoorbeeld Citigroup, Merill Lynch en Morgan Stanley, Nasdaq, de private equitygroepen Carlyle en Blackstone, en de chipfabrikant AMD. Dit geldt temeer nu de deelnemingen in Carlyle en Morgan Stanley blijken grote verliezen op te leveren. Deze verliezen zullen verantwoord moeten worden aan het Chinese Nationale Volkscongres. Zou de politiek kunnen besluiten dat de aandeelhoudersrechten, nu het toch om een verliesgevende investering gaat, maar beter kunnen worden gebruikt om tenminste een politieke doelstelling te realiseren, zoals het stopzetten of anderszins beïnvloeden van commercieel verkeer met Taiwan of Tibet?

Het is dus denkbaar dat staatsfondsen hun zeggensmacht in strijd met het vennootschappelijk belang uitoefenen Op dit moment maakt de Nederlandse regering zich geen zorgen, maar de omvang van hun vermogen, het fenomenale bedrag van $\$ 3.000$ miljard, bijna drie maal zoveel als het 
vermogen van de hedge funds, én het gebrek aan transparantie dat staatsfondsen kenmerkt, zou tot een behoedzamer houding moeten dwingen. De Nederlandse regering stelt wel dat, zonodig, beursgenoteerde ondernemingen gebruik kunnen maken van beschermingsmaatregelen, maar mijn constatering is nu juist dat ten onrechte vertrouwen in de Nederlandse juridische beschermingsmaatregelen wordt gesteld. De door de regering met de verwijzing naar de beschermingsconstructies toegeworpen reddingsboei zou daarom wel eens geen drijfvermogen kunnen blijken te hebben.

Ter voorkoming van misverstand wijs ik erop dat 'beschermen mág'. Wij zagen dat de rechter bescherming toestaat. Ook de wetgever doet dat, en wel in art. 2:118a BW dat ondanks aandrang daartoe niet is geschrapt.

Er bestaat echter een onmiskenbare tendens tégen certificering als beschermingsmaatregel en ondanks het handhaven van de leden $2 \mathrm{t} / \mathrm{m} 4$ van art. 2:118a BW zou certificering geen beschermingswal maar slechts een beschermingshobbeltje kunnen blijken.

Met preferente beschermingsaandelen is het nog slechter gesteld. 
HOOFDSTUK 5

PREFERENTE BESCHERMINGSAANDELEN EN NEDERLANDSE CONCLUSIE

Waar de trend tégen certificering is, valt een omgekeerde waardering van preferente aandelen als beschermingsmaatregel waar te nemen. Volgens mij is deze beschermingsmaatregel geldig noch houdbaar.

De technische beschrijving is dat zij niet boven een bepaald percentage van het nominale bedrag of slechts in beperkte mate daarboven delen in de winst of in het overschot na vereffening delen en daarom kunnen worden uitgegeven tegen storting van slechts - de nominale waarde zonder dat dit voor de overige aandeelhouders financiële verwatering veroorzaakt. In de praktijk kan voorts gebruik worden gemaakt van de mogelijkheid die art. 2:80 jo. $82.3 \mathrm{BW}$ biedt, zodat van het nominale bedrag slechts een kwart behoeft te worden volgestort.

De ontbrekende schakel in de redenering is dat de koers uitsluitend wordt gebaseerd op financiële overwegingen, maar dat de emissie uitsluitend plaatsvindt op grond van zeggenschapsoverwegingen. De waarde van die zeggenschap wordt op nihil gesteld.

Bovendien wordt de emissie niet realistisch gefinancierd door middel van een banklening zónder zekerheid aan een stichting zonder vermogen.

Welke bank is bereid een niet gesecureerde lening te verstrekken? Het antwoord op deze vraag kan alleen gevonden worden door te verwijzen naar de relatie tussen de bank en de vennootschap die de aandelen uitgeeft. Die relatie moet impliceren dat de bank ter zake van het debiteurenrisico van de stichting op de vennootschap vertrouwt. Dit is een situatie die dicht in de buurt komt van het financieringsverbod van art. 2:98c BW.

Dit risicoprofiel wordt miskend met de redenering dat het gaat 
preferente beschermingsaandelen die gedurende een beperkte periode uitstaan en aan het eind van die periode worden ingekocht en ingetrokken. Volgens mij kunnen redelijk handelende bestuurders van vennootschappen en stichting dit niet volhouden. Kredietcrises, devaluaties, fraudegevallen, deconfitures van belangrijke klanten, toeleveranciers of financiers, en tal van andere niet te voorspellen gebeurtenissen kunnen zich onaangekondigd voordoen, en dus ook gedurende de periode dat de preferente beschermingsaandelen uitstaan. Indien een dergelijke calamiteit zich mocht voordoen, betekent dit het faillissement van de vennootschap én van de stichting. Het risico van bestuurdersaansprakelijkheid komt in zicht.

Ik heb eerder betoogd dat het hier niet gaat om een reële emissie, maar om een schijnhandeling, vergelijkbaar met de nietige schijnhandeling beschreven in het - oude - HVA/Westertoren Iarrest.

Ik voeg daaraan toe dat de geoorloofdheid van de oorzaak van de verschillende overeenkomsten die tezamen de transactie vormen, naar mijn oordeel niet vaststaat. Ik sluit een mogelijke nietigheidsactie op grond van art. 3:40 BW niet uit omdat het aangaan van de lening, het nemen van de preferente beschermingsaandelen en de beperkte volstorting, op zichzelf genomen geoorloofde transacties, met elkaar in verband gebracht dwingen tot de conclusie dat zij met 'laakbare intenties' zijn overeengekomen. De feitelijke overtreding van het verbod van financiële assistentie door de vennootschap als vervat in art. 2:98c BW en tot het onmogelijk maken van nakoming van aangegane verbintenissen bij onverwachte, maar niet uit te sluiten, plotselinge calamiteiten komen neer op het beogen van het ontduiken van de wettelijke bepaling van art. 2:98c BW en op het tot stand brengen van een samenstel van rechtshandelingen die een schijnhandeling opleveren. Dergelijke acties worden op zich, en tezamen genomen, bedreigd door de sanctie van nietigheid. 
In de voorgaande hoofdstukken is vooral de Nederlandse praktijk besproken.

In vergelijking met de andere continentaal-Europese jurisdicties lijkt Nederland gaandeweg een betrekkelijk geïsoleerde positie te zijn gaan bekleden. Waar in die andere jurisdicties structurele belemmeringen tegen niet geïnviteerde overnames en aandeelhoudersactivisme bestaan en blijven bestaan, bieden de technische beschermingsmaatregelen in Nederland minder of geen soelaas. Voor Nederland bestaat op die grond een zekere achterstand op het level playing field.

Gegeven deze wellicht onevenwichtige situatie zal ik verkennen hoe in andere jurisdicties wordt omgegaan met niet geïnviteerde overnames en aandeelhoudersactivisme en vervolgens onderzoeken of bepaalde vormen van bescherming die in het buitenland gebruikelijk zijn, zich lenen voor toepassing in Nederland. 
HOOFDSTUK 6 INTERNATIONAAL; EUROPA

In Nederland is sprake van 'technische' beschermingsmaatregelen, in hoofdzaak juridische bescherming in de vorm van statutaire bepalingen. Wij zijn nauwelijks bekend met het verschijnsel 'structurele' bescherming dat zich in andere jurisdicties voordoet in de vorm van familieaandeelhouderschap, overheidsaandeelhouderschap, aandelenpiramides of aandeelhouderschap door intermediairs zoals banken.

\section{...Duitsland}

In Duitsland is op grote schaal sprake van structurele bescherming doordat beleggers hun aandelen in de regel niet direct houden maar giraal via banken die het stemrecht namens hun cliënten uitoefenen.

Duitsland kent daarom structurele belemmeringen voor het uitoefenen van aandeelhoudersmacht, met name bestaande uit de intermediairfunctie van banken die feitelijk de aan de kapitaalverschaffing verbonden zeggenschap namens hun cliënten uitoefenen.

\section{...Frankrijk}

In Frankrijk is sprake van structurele barrières voor de uitoefening van zeggensmacht proportioneel met het kapitaal belang vanwege de mogelijkheid van dubbel stemrecht op aandelen, aandelen in handen van een bepaalde categorie aandeelhouders, met name families maar ook de overheid en werknemers, en het toegestaan zijn en toegepast worden van piramidestructuren.

De overheid betoont zich van tijd tot tijd een beschermer van het nationaal karakter van Franse ondernemingen. Onlangs deed de Franse president opmerkelijke uitspraken naar aanleiding van het schandaal bij Société Générale. Hij verklaarde dat de Franse overheid niet zou toezien indien een partij gebruik zou maken 
van de kwetsbare positie van de bank, daarmee suggererend dat maatregelen zouden worden genomen of toegestaan die een dergelijke overname blokkeren.

Er bestaan in Frankrijk structurele belemmeringen vanwege het aandeelhouderschap van de overheid en technische barrières, bijvoorbeeld in de vorm van meervoudig stemrecht. De bescherming van vennootschappen kan ad hoc, en voor derden moeilijk voorzienbaar, worden versterkt door actief overheidsingrijpen wanneer naar het oordeel van de overheid sprake is van bedreiging van het nationaal karakter van een Franse vennootschap met een publiek belang.

\section{...Italië en Spanje}

Italiaanse vennootschappen worden veelvuldig gehouden in de vaste handen van een of meer families, hetgeen direct of indirect kan geschieden.

Italiaanse ondernemingen kennen in sterkere mate dan in Frankrijk het geval is, de Italiaanse overheid als belangrijke aandeelhouder.

Ook in Spanje wordt een belangrijk aantal vennootschappen gecontroleerd door families. Bovendien houdt in 10\% van de Spaanse vennootschappen een Spaanse bank het grootste belang. In tegenstelling tot Frankrijk en Italië is in Spanje geen sprake van overheidsparticipatie in het aandelenkapitaal van genoteerde vennootschappen.

Ook in Italië en Spanje bestaan structurele belemmeringen vanwege het aandeelhouderschap van de overheid (alleen in Italië) en families.

\section{...Verenigd Koninkrijk}

De verhandeling over het Verenigd Koninkrijk kan kort zijn. In dit land bestaan geen vergelijkbare structurele of technische barrières die de kapitaalverschaffer hinderen of belemmeren bij het uitoefenen van zeggensmacht die proportioneel is met de kapitaalsbijdrage. In deze jurisdictie vinden dan ook relatief veel 
vijandige overnames plaats en hebben aandeelhouders de mogelijkheid het beleid van de onderneming wezenlijk te beïnvloeden.

\section{...Dertiende Richtlijn}

Ik volsta met de constatering dat de oorspronkelijke doelstelling nauwelijks is gerealiseerd.

De conclusie op het Europese level playing field luidt dat in Duitsland, Frankrijk, Italië en Spanje sprake is van structurele belemmeringen, veelal in combinatie met de mogelijkheid van technische belemmeringen, dit in tegenstelling tot de situatie in het Verenigd Koninkrijk. In Nederland is de situatie weer anders omdat de Nederlandse praktijk geen structurele belemmeringen kent, maar wel een vrij uitgebreid stelsel van technische belemmeringen. Deze zijn in het kader van de corporate governance discussie in toenemende mate onder vuur komen te liggen. 
Ten aanzien van de Verenigde Staten bestaat het beeld dat het shareholders-model meebrengt dat in de vennootschappelijke organisatie aan aandeelhoudersbelangen prioriteit wordt verleend en dat ruim baan bestaat voor niet geïnviteerde overnames en aandeelhoudersactivisme. Dit is onjuist.

Het aandelenbezit is wijdverbreid en in vergelijking met de zojuist genoemde Europese jurisdicties is er nauwelijks sprake van geconcentreerd aandelenbezit. Dit verschijnsel van dispersed ownership veroorzaakt twee effecten.

In de eerste plaats hebben aandeelhouders een collective action problem dat hen belemmert hun disciplinerende taak, de controle van het bestuur, uit te oefenen. Actie wordt ontmoedigd door de buitengewoon hoge kosten van aandeelhoudersactie in combinatie met het probleem van de free rider, die profiteert van de aandeelhoudersactie maar niet bijdraagt in de kosten ervan. In de tweede plaats en in het verlengde van de feitelijk minder aanwezige aandeelhouderscontrole is sprake van managerialism; versterkte bestuursmacht die een grote marge biedt bij het invullen van de fiduciary duties van het bestuur jegens de aandeelhouders.

In de Amerikaanse juridische literatuur is in de daar gevoerde discussie gesteld dat aandeelhoudersinvloed, als die al wordt gegeven, tegelijkertijd een uitnodiging aan het management inhoudt om over te gaan tot embedded defenses, beschermingsmaatregelen die niet door aandeelhouders, maar door het management worden opgetuigd. Een voor mij nog verrassender argument keert zich tegen de aanname dat ondernemingen lager zouden worden gewaardeerd wanneer zij statutaire beschermingsmaatregelen treffen. Met empirische ondersteuning wordt gesteld dat juist de dreiging van de veel duurdere vervangende beschermingsmaatregelen, in de vorm van 
de zojuist genoemde embedded defenses waartoe aandeelhouders het management met hun zeggenschapsclaim zouden verleiden, leidt tot een lagere waardering van het aandeel. Hiermee is overigens een interessante aanvullende grond gegeven om te betwijfelen of de beruchte Dutch Discount, waarvan het bestaan niet op empirisch wijze overtuigend is aangetoond, kan bestaan.

Aandeelhouders in de Verenigde Staten kunnen niet of slechts met moeite en tegen hoge kosten opkomen tegen de door het management beheerste beschermingsmaatregelen. Deze beschermingspraktijk in de Verenigde Staten is veelzijdig en bedient zich van een rijk taalgebruik. Ik volsta met enige schetsen.

De meest voorkomende bescherming is die van de poison pill, zoals een shareholders rights plan, waarbij bestaande aandeelhouders bij een overval aandelen kunnen nemen tegen aantrekkelijke prijzen, zodanig dat het aandelenbezit van de vijandige bieder verwatert.

Ook een staggered board waardoor bestuurders een lange en niet opzegbare bestuurstermijn hebben, is effectief. Men hanteert voorts meervoudig stemrecht, of super voting; aandelen die gelijken op Nederlandse beschermingspreferente aandelen. Tot slot noem ik de mogelijkheid om een white knight tot een overname te verleiden met aantrekkelijke voorwaarden die niet aan de vijandige bieder toekomen, aandelen die aan het personeel tegen gunstige voorwaarden worden uitgegeven, en vele overige statutaire bepalingen die het de vijandige overnemer onmogelijk maken of bemoeilijken om zeggensmacht uit te oefenen.

Aan dit overzicht moet worden toegevoegd dat in de Verenigde Staten ook sprake is van bescherming door middel van contractuele regelingen, die niet althans niet noodzakelijkerwijze tevens beschermingsmaatregel zijn, maar wel een beschermend effect hebben. Ik geef hiervan twee voorbeelden. 
Het eerste voorbeeld betreft de zaak Air Line Pilots Association, International v. UAL Corporation.

In het kader van de strategie om een fullservicereisorganisatie te creëren kocht United Air Lines Incorporated (de moedermaatschappij van United Airlines, hierna: UAL) in 1985 het Hertz-concern en in 1986 het Hilton-concern. De gevolgde strategie bleek al in 1987 niet succesvol te zijn. De koers van het aandeel UAL daalde sterk en er ontstond onrust onder de werknemers en aandeelhouders van UAL. De Air Line Pilots Association (hierna: de pilotenbond) welke de belangen van de piloten vertegenwoordigde, deed vervolgens in het begin van 1987 een poging om UAL over te nemen door middel van een bod op de aandelen van UAL. De pilotenbond slaagde erin om de financiering voor het bod van $\$ 4,5$ miljard te arrangeren. Bij een succesvolle overname zou de vliegtuigbusiness worden afgescheiden van de hotel- en autoverhuurbusiness. De piloten en overige werknemers zouden deelnemen in het aandelenkapitaal door middel van een Employee Stock Ownership Plan (ESOP). Het voorstel werd aan het bestuur voorgelegd en was voor onderhandeling vatbaar.

Het bestuur van UAL hield vast aan de strategie en verweet de piloten de vennootschap in play te hebben gebracht. Vervolgens verzekerde het bestuur zich op sinistere wijze van de steun van de International Association of Machinists \& Aerospace Workers (hierna: IAM), welke ongeveer een derde van het personeel van UAL vertegenwoordigde, door aan de IAM allerlei voordelen toe te kennen. Daardoor daalde de waarde van de onderneming zodanig, dat voortzetting van het bod voor de Pilotenbond geen zin had. De pilotenbond betwistte de geldigheid van de regelingen in rechte omdat ze in feite een beschermingsmaatregel, en niet een arbeidsrechtelijke regeling, waren. De rechtbank overwoog op grond van de business judgement rule dat besluiten van bestuurders welke zijn genomen met inachtneming van de toepasselijke formaliteiten, in beginsel niet aangetast kunnen worden. Op grond van de omstandigheden van 
het geval oordeelde de rechter echter dat er sprake was van een beschermingsmaatregel, waarbij het belang van het bestuur om controle over de vennootschap te behouden tegenover het belang van de aandeelhouders komt te staan, namelijk de maximalisatie van aandeelhouderswaarde. In dit uitzonderingsgeval werd het bestuursbesluit inhoudelijk getoetst aan de hand van de Unocal-test. De rechtbank oordeelde dat het bod onterecht als inadequaat en als een bedreiging was bestempeld.

De tweede eis van de Unocal-test is dat de getroffen maatregel redelijk dient te zijn in relatie tot de bedreiging welke zich voordoet. De rechtbank oordeelde dat de proportionaliteit in dit geval ontbrak omdat de bestreden bepalingen in een overeenkomst waren opgenomen en kwalificeerden als beschermingsmaatregel die niet door het bestuur eenzijdig ongedaan kon worden gemaakt, hetgeen bij de gebruikelijke statutaire beschermingsmaatregelen wel het geval is. In het licht hiervan werd de beschermingsmaatregel dan ook 'dodelijker' geoordeeld dan poison pills.

Het tweede voorbeeld betreft de zaak Oracle v. PeopleSoft. In deze zaak introduceerde PeopleSoft naar aanleiding van het vijandige bod van Oracle in juni 2003 - naast onder andere golden and tin parachutes - het Customer Assurance Program (hierna: CAP) inhoudende dat klanten twee- tot vijfmaal het bedrag van de door hen betaalde licenties zouden terugkrijgen wanneer PeopleSoft zou worden overgenomen en daarmee de ondersteuning van de software van PeopleSoft zou verminderen. Het bod van Oracle dreigde deze betalingsverplichting te activeren omdat niet vast stond dat Oracle de door PeopleSoft aanvaarde verplichtingen zou kunnen of willen nakomen. De mogelijke aansprakelijkheid onder het CAP liep op tot een bedrag van $\$ 2$ miljard. In de daaropvolgende procedure stelde Oracle dat het aangaan van het CAP in strijd was met de in Unocal geformuleerde criteria en meer in het algemeen dat het bestuur handelde in strijd met de fiduciary duties. Het is in deze 
zaak niet tot een rechterlijk oordeel gekomen en PeopleSoft heeft haar verzet opgegeven nadat het bod van Oracle was verhoogd tot $\$ 26,50$ per aandeel. Kennelijk is het daarna niet tot betalingsverplichtingen onder het CAP gekomen.

De hiervoor besproken Unocal-test is enigszins vergelijkbaar met de eveneens hiervoor besproken RNA-norm en bedoeld als maatstaf ter beoordeling of er sprake is van een geoorloofde beschermingsmaatregel. Volgens deze test dient het bestuur van de doelvennootschap aan te tonen dat het vijandige bod een bedreiging vormt voor de uitvoering van de vennootschappelijke strategie en dat de genomen maatregel redelijk is in verhouding tot de bedreiging. De lat om dit aan te tonen ligt echter niet hoog. In het uitzonderlijke geval van de $U A L$-zaak, waar naar het oordeel van de rechter sprake was van unique lethality, slaagde het bestuur niet in deze bewijslast. Gezien de Amerikaanse praktijk waarin vijandige overnames zelden slagen en procedures bepaald geen uitzondering vormen, moet worden aangenomen dat beschermde ondernemingen al gauw voldoen aan de test en erin slagen hun bescherming effectief in te zetten.

Er bestaan wel grenzen aan de bestuursvrijheid om zich achter beschermingsmaatregelen te verschansen. Deze grenzen worden aangegeven door middel van de zogenoemde Revlon-doctrine. Zodra een vennootschap in play is, dat wil zeggen dat de overname gegeven is, heeft het bestuur zich te richten naar de aandeelhoudersbelangen en dient hij een level playing field te creëren waarop de aandeelhouders de hoogst mogelijke opbrengst voor hun aandelen kunnen realiseren. De Revlondoctrine richt zich op de normering van bestuurshandelen en geeft aan dat het bestuur in een bepaalde situatie zich heeft te richten op de verwezenlijking van de belangen van de aandeelhouders. Deze shareholders-benadering vindt dus alleen plaats wanneer duidelijk is dat de vennootschap zal worden overgenomen en alleen in dat geval dient het bestuur zich te richten op de maximalisatie van aandeelhouderswaarde. Deze norm is door de 
A-G in de $A B N$ Amro-zaak aan de Hoge Raad voorgehouden.

In de Verenigde Staten wordt de aansprakelijkheid van bestuurders in belangrijke mate gekleurd door een concept dat in Nederland in die vorm niet bekend is. Het gaat om de business judgement rule die bepaalt dat de besluiten van bestuurders welke zijn genomen met inachtneming van de toepasselijke formaliteiten, in beginsel niet aangetast kunnen worden en dat bestuurders voor die besluiten niet aansprakelijk zijn. Aan de bestuurders wordt een zeer ruime vrijheid en beleidsmarge gelaten om te ondernemen en met name om de aan het ondernemen verbonden risico's te nemen zonder dreiging van persoonlijke aansprakelijkheid voor hun handelen.

Ook naar Nederlands recht wordt aan bestuurders ruimte geboden om te ondernemen en de daaraan verbonden risico's te lopen. In artikel 2:9 BW is tot uitdrukking gebracht dat het bestuur de vrijheid moet hebben om te ondernemen, en dus om risico's te nemen. Naast de noodzaak van het verschaffen van beleidsvrijheid om ondernemingsrisico te nemen, staat de noodzaak om bestuurders voor onverantwoord gedrag te kunnen aanspraken. Het is in de praktijk lastig om het evenwicht aan te brengen tussen deze twee elementen van het bestuurderschap. Een voorzichtige conclusie luidt dat het bestaan van de business judgement rule in de Verenigde Staten leidt tot een afstandelijker toetsing dan de marginale toetsing die in Nederland plaatsvindt. Wanneer men onder de term 'bestuurdersaansprakelijkheid' ook rekent het gevaar om als bestuurder blootgesteld te worden aan een enquête, zal de conclusie minder voorzichtig zijn en luiden dat in Nederland een hogere mate van dreiging van bestuurdersaansprakelijkheid bestaat dan in de Verenigde Staten het geval is.

In de Verenigde Staten is sprake van een levendige en gevarieerde praktijk van het hanteren van beschermingsmaatregelen, waarbij de rol van de board dominant is. In de Verenigde Staten gaat het om specifiek als bescherming 
tegen vijandige overnames gerichte beschermingsmaatregelen, terwijl het in de hierboven beschreven continentaal-Europese jurisdicties, anders dan in Nederland, vooral gaat om structurele barrières die niet zijn ingericht als beschermingsmaatregelen, maar wel het feitelijk effect van beschermingsmaatregelen hebben.

In Nederland blijkt geen sprake te zijn van feitelijke of structurele bescherming die vergelijkbaar is met de overige genoemde continentaal-Europese jurisdicties. De Nederlandse praktijk gehanteerde technische beschermingsmaatregelen blijken minder houdbaar. Waar in de Verenigde Staten sprake is van een beschermingspraktijk door middel van technische beschermingsmaatregelen die gelijkt op de Nederlandse praktijk, is in de Verenigde Staten in mindere mate sprake van druk om bescherming tegen te gaan.

Welke oplossing is er dan voor handen voor het bestuur om de vennootschap te beschermen tegen niet geïnviteerde overnames en activistische aandeelhouders, indien tenminste op redelijke gronden mag worden aangenomen dat een dergelijke overname of dergelijke machtsuitoefening zal leiden tot inbreuk op het vennootschappelijk belang? 
HoOFDSTUK 8 TERUG NAAR DE NEDERLANDSE PRAKTIJK

Teruggaande naar de Nederlandse praktijkwijs ik opnieuw naar het ijkpunt van het vennootschappelijk belang. Art. 2:118a BW leert dat het vennootschappelijk belang beschermingsmaatregelen kan rechtvaardigen. Er zijn meer nationale en internationale aanknopingspunten, bijvoorbeeld kijkend naar de opvattingen over maatschappelijk verantwoord ondernemen:

- de OESO Richtlijnen voor Multinationale Ondernemingen bepalen:

Enterprises should take fully into account established policies in the countries in which they operate, and consider the views of other stakeholders. In this regard, enterprises should contribute to economic, social and environmental progress with a view to achieving sustainable development.

- $\quad$ het advies van de SER 'De winst van waarden' bepaalt: Ondernemingen onderscheiden zich van andere organisaties door het streven naar winst. Het zou echter onjuist zijn de maatschappelijke en economische betekenis van ondernemingen te reduceren tot de uitkomsten van dit streven en daarmee gelijk te stellen aan de financiële opbrengsten voor eigenaren/kapitaalverschaffers. Ondernemingen scheppen waarde door schaarse middelen - kapitaal, arbeid, kennis en organisatievermogen alsmede natuurlijke hulpbronnen - op een efficiënte en effectieve manier in te zetten voor de voortbrenging van goederen en diensten die door het bevredigen van behoeften van mensen bijdragen aan de maatschappelijke welvaart. De werkgelegenheid die daarbij wordt geschapen is een belangrijk middel voor inkomensverwerving en voor maatschappelijke en persoonlijke ontplooiing van mensen. De inkomensvorming in de onderneming legt ook de basis voor de financiering (via belasting en premieheffing) van collectieve voorzieningen.

De modernisering uit 2006 van het vennootschapsrecht in het Verenigd Koninkrijk heeft geleid tot wezenlijke herziening van de UK Companies Act 1985. Eén van de meest spraakmakende bepalingen is Section 172 waarin het concept van enlightened 
shareholders value wordt gecodificeerd:

A director 'must act in the way he considers, in good faith, would be most likely to promote the success of the company for the benefit of its members as a whole'.

Onder success wordt dan verstaan de long-term increase in value voor de aandeelhouders en bij het streven naar dit succes dienen bestuurders een lange termijn visie te hebben, rekening te houden met de belangen van de werknemers, te streven naar versteviging van de band met toeleveranciers, klanten en anderen en tevens rekening te houden met het effect van de werkzaamheden van de onderneming op de gemeenschap en het milieu. Bovendien dient het bestuur te streven naar een goede reputatie op het gebied van ondernemersgedrag en de aandeelhouders fair te behandelen. Bij het nastreven van de aandeelhoudersbelangen onder dit model dient ook rekening te worden gehouden met de belangen van de andere stakeholders dan alleen de aandeelhouders. Die andere stakeholders hebben echter geen actie, althans niet onder het vennootschapsrecht.

Naar Nederlandse maatstaven zouden de stakeholders wel over actiemogelijkheden beschikken, bijvoorbeeld onder het enquêterecht, de collectieve actie en wellicht ook op grond van art. 2:8 BW.

Niettemin levert deze constatering voor de Nederlandse situatie niet veel concrete aanknopingspunten op. In de Stork-casus verliepen de zaken uiteindelijk zoals de activistische aandeelhouders wensten. $\mathrm{Bij}$ de $A B N$ Amro-casus was sprake van een ruime mate van beleidsvrijheid aan de zijde van het bestuur waar het ging om de verkoop van de strategische deelneming in de Amerikaanse dochter LaSalle, maar de keuze voor de geprefereerde fusiekandidaat is volledig in handen geweest van de aandeelhouders die massaal kozen voor het door het bestuur ontraden alternatief.

In de PCM-casus was het wellicht wenselijk geweest dat de aandeelhouders belemmeringen hadden ondervonden bij het uitoefenen van hun rechten. Ik zal Section 172 van de 
Companies Act parafraseren en op die manier het handelen van het bestuur van PCM beschrijven gedurende de periode dat de activistische aandeelhouders hun invloed op de onderneming deden gelden: er was allerminst sprake van een toestand waarin het bestuur van PCM streefde naar een long-term increase in value voor de aandeelhouders, het bestuur beschikte niet over een lange termijn visie en hield geen rekening met de belangen van de werknemers en het verstevigen van de band met toeleveranciers, klanten en anderen, en evenmin met het effect van de werkzaamheden van de onderneming op de gemeenschap en het milieu. In zowel het enlightened shareholders-model als het stakeholders-model zou het onder dergelijke omstandigheden denkbaar en gerechtvaardigd zijn dat het bestuur van de doelvennootschap een barrière opwerpt tegen de uitoefening van aandeelhoudersmacht. Onder beide modellen kan worden geconcludeerd tot een bedreiging voor het vennootschappelijk belang.

Zo ben ik gekomen tot de constatering dat onder de beschreven omstandigheden bescherming wenselijk moet worden geacht, maar ook dat in Nederland minder ruimte bestaat om die bescherming te zoeken in de traditionele beschermingsmaatregelen. Ik zal hier geen pleidooi houden voor het herwaarderen van de kracht en houdbaarheid van beschermingsmaatregelen en de onmiskenbare 'anti-stemming' tot uitgangspunt nemen. De vraag is dan of ondernemingen die te maken hebben met een niet geïnviteerde overname of activistische aandeelhouder zich in beginsel hebben te richten naar de wensen en verlangens van deze partijen of dat bestuurders van deze ondernemingen middelen kunnen vinden om toch een barrière op te werpen.

Bij het verkennen van een antwoord op deze vraag geldt een voorwaarde en een notie.

De voorwaarde is dat bescherming alleen houdbaar kan zijn wanneer zij wordt getroffen met het oog op het 
vennootschappelijk belang.

De notie is dat het bestuurshandelen om die maatregelen tot stand te brengen slechts marginaal getoetst zal worden.

Het bestuurshandelen vindt plaats tegen de achtergrond van de continuïteitsgedachte. De rechtspersoon wordt voor onbepaalde tijd opgericht, art. 2:17 BW, en ook in de accountantsverklaring ligt de continuïteitsaanname besloten, art. 2:384 lid 3 BW. Het hiervoor aangehaalde citaat uit het SER-advies 'De winst van waarden' gaat uit van de continuïteitsgedachte. Ook in de shareholders-modelbenadering naar Amerikaans recht, is het de takk van het bestuur om te waken over de continuïteit van de vennootschap. De gedachte maakt deel uit van de Revlon-doctrine en is aangehaald door de A-G in de conclusie bij de $A B N$ Amrozaak. Vanwege de vergaande zeggenschapsrechten van aandeelhouders kán aandeelhoudersinvloed leiden tot discontinuïteit. Ondernemingen kunnen zich daartegen beschermen door change of control-clausules of bepalingen die daarop lijken. In het navolgende zal ik nader ingaan op die praktijk.

Geïnspireerd door de casus van UAL en PeopleSoft zou ik mij de volgende praktijksituaties kunnen voorstellen:

\section{...voorbeeld softwarehuis}

Een softwarehuis kan in een service level agreement of een 'loyaliteitsplan' vastleggen dat bepaalde diensten worden geleverd onder de garantie van continuïteit daarvan, met een boeteclausule bij inbreuk daarop. Dat levert een concurrentievoordeel aan de leverancier en een waarborg voor de klant. Het is evident dat het belang van het softwarehuis, én dat van alle bij het softwarehuis betrokkenen, daarmee is gediend.

Deze constatering wordt niet anders wanneer na het sluiten van dergelijke overeenkomsten blijkt dat het softwarehuis het doel van een niet geïnviteerde overname wordt. Dat is evenmin het geval wanneer de bieder een hardwarehuis zou zijn dat alleen 
software wenst te ondersteunen dat 'draait' op haar platform, of een concurrerend softwarehuis dat de software van de doelvennootschap wenst te integreren in de door haar op de markt gebrachte software. Het is denkbaar dat het overnemende hardwarehuis of softwarehuis besparingen of efficiënties wenst na te streven die in strijd komen met de voorwaarden van het loyaliteitsplan. Het is ook denkbaar dat de overname zelf een inbreuk oplevert op de bepalingen van het loyaliteitsplan. In deze gevallen heeft de overnemer te vrezen voor dreigende of acute problemen in de continuiteit van de relaties met de klanten van het overgenomen softwarehuis welke problemen nog aanmerkelijk verergerd kunnen worden indien de overname leidt tot het opeisbaar worden van de boete onder een boeteclausule. Wanneer dergelijke dreigende gevaren aan de niet geïnviteerde bieder kenbaar worden gemaakt, zal deze op grond daarvan kunnen afzien van voortzetting van de overnamepoging.

De hier beschreven contractuele regeling is tot stand gekomen in de normale bedrijfsuitoefening van het softwarehuis, werd door de markt verwelkomd, heeft geleid tot verbetering van de resultaten van het softwarehuis en strekte tot vervulling van het vennootschappelijk belang van het softwarehuis. De bekendmaking van het loyaliteitsplan en de analyse van de mogelijke effecten daarvan welke leidt tot het afbreken van de overnamepoging, waren geen doelstelling toen het loyaliteitsplan met de betreffende klanten werd onderhandeld en overeengekomen. Er is sprake van een geldige overeenkomst die in overeenstemming met wat het vennootschappelijk belang vordert is gesloten en waarvan het effect is dat zij de onderneming beschermt tegen niet geïnviteerde overnames.

\section{...voorbeeld farmaceutisch bedrijf}

Een vergelijkbaar voorbeeld kan worden gegeven voor een farmaceutisch bedrijf dat bij de ontwikkeling van een nieuw geneesmiddel grote investeringen moet doen. Een dergelijk risico kan worden gedeeld met andere marktpartijen, zoals distributeurs 
van medicijnen. Deze zal bij een niet geïnviteerde overname het recht willen bedingen de distributieovereenkomst te beëindigen tegen een door het farmaceutisch bedrijf te betalen vergoeding gebaseerd op de contant gemaakte waarde van de winsten over de nog resterende looptijd van de distributieovereenkomst.

\section{...voorbeeld modekoning}

Ook een modeontwerper moet voor nieuwe ontwerpen grote investeringen doen, die hij kan delen met winkels of winkelketens door exclusiviteitsregelingen versterkt door boetebepalingen en beëindigingsmogelijkheden ingeval van een niet geïnviteerde overname.

\section{...voorbeeld retailonderneming}

Retailondernemingen kunnen een commercieel voordeel bereiken via het beleid ten aanzien van de locaties waarin de keten gevestigd is. De concurrentie bij het verwerven van de locaties is vrijwel steeds heftig en in die concurrentiestrijd zou de retailketen kunnen garanderen dat zij controle houdt over de ketenformule, dat deze niet wezenlijk zal wijzigen en dat in geval van inbreuk op die garantie de (huur)overeenkomst voortijdig eindigt.

Deze bepaling geeft de retailketen de mogelijkheid om ondanks de concurrentiestrijd een locatie ter beschikking te verkrijgen en aldus de verkoop van haar producten te bevorderen. De bepaling verschaft voorts aan de contractuele wederpartij, meestal de verhuurder, een redelijke zekerheid dat het gebruik van het pand geschiedt en blijft geschieden op de wijze zoals vastgelegd in de overeenkomst en dat bij wijziging van het beleid van de retailondernemer het contract wordt beëindigd en kan worden heronderhandeld. In de praktijk zal dit vrijwel steeds leiden tot een huur- of andere prijsverhoging. Het kan zijn dat deze bepaling tot gevolg heeft dat de verkoop van de retailonderneming aan bepaalde kopers onaantrekkelijk of zelfs economisch onhaalbaar wordt, maar dit gevolg was geen doelstelling van de betreffende overeenkomst. 


\section{...voorbeeld financiële instelling}

Banken leggen zich toe op een breed scala van diensten en opereren in een markt van hevige concurrentie. Individuele banken kunnen zich onderscheiden door de industrietak die zij in het bijzonder bedienen, het specifieke marktsegment dat zij aanboren, de bijzondere diensten die zij verrichten en op vele andere terreinen. In dat verband zullen zij regelmatig over gevoelige informatie over hun klanten beschikken. Klanten zullen in sommige gevallen verlangen dat die informatie niet alleen wordt beschermd door de 'Chinese muren' en verdergaande bescherming wensen. De bank zou zich in dat verband kunnen verbinden om geen concurrerende ondernemingen als klant toe te laten of zou garanties kunnen geven dat de bijzondere informatie over de klant vertrouwelijk blijft. Het belang van de bank is daarmee gediend.

Deze constatering wordt niet anders wanneer na het sluiten van dergelijke overeenkomsten blijkt dat de bank het doel van een niet geïnviteerde overname wordt. Dat is evenmin het geval wanneer de bieder in dit geval een concurrerende bank is die nu juist in de bijzondere klantrelaties van de doelbank is geïnteresseerd. Het is denkbaar dat de overname een inbreuk oplevert op de bepalingen van de geen klanten-overeenkomst. In dat geval heeft de overnemer te vrezen voor dreigende of acute problemen in de continuiteit van de relaties met die klanten hetgeen ertoe kan leiden dat wordt afgezien van voortzetting van de overnamepoging.

Naar aanleiding van de in de pers verschenen berichten over de loyaliteitsbonussen die aan werknemers van ABN Amro in het vooruitzicht werden gesteld om een leegloop te verhinderen ten tijde van het overnamegevecht, maak ik nog de volgende opmerking. Het kan zijn dat het totale bedrag dat met deze uitkeringen gemoeid is vanwege de bijzonder hoge overnamesom van meer dan $€ 70$ miljard niet gekwalificeerd kan worden als een Pandora-constructie of als een transactie waarvan op andere 
gronden de geldigheid zou kunnen worden aangetast. Er bestaat echter wel aanleiding om te vermoeden dat het indirecte effect van deze regeling door het overnemende consortium als belemmerend wordt ervaren. Door de bonusregeling wordt immers bevorderd dat personeelsleden op hun post blijven, terwijl hun positie in het kader van het streven naar synergie overbodig zal worden. Het aanblijven van de betreffende werknemers, die zonder een dergelijke bonus wellicht op een eerder moment naar een andere werkgever zouden zijn vertrokken, staat het verwezenlijken van de synergievoordelen in de weg en betekent het voortduren van kosten gedurende een langere periode dan voorzien. De blijvende aanwezigheid van werknemers voor wie feitelijk geen plaats meer is, kan voorts het doorvoeren van de nieuwe strategie na de overname belemmeren.

\section{...voorbeeld industriële onderneming}

Grote industriële ondernemingen zouden een Most Favored Nation-clausule met een belangrijke afnemer kunnen overeenkomen en garanderen dat deze altijd tegen de laagste door die onderneming gehanteerde prijs de betreffende goederen kan verkrijgen. Indien sprake is van een overname door een concurrerende onderneming die aan dezelfde afnemer levert, zal deze concurrerende onderneming sterke druk ondervinden om ook haar prijzen aan de afnemer te verlagen.

\section{... algemene voorbeelden; ondernemingsraad}

Naar mijn mening is de rol van de ondernemingsraad in de recente voorbeelden van met name Stork en ABN Amro onvoldoende tot uitdrukking gekomen.

In het kader van het onderhouden van goede relaties met de ondernemingsraad kunnen de ondernemer en de ondernemingsraad besluiten tot het toekennen aan de ondernemingsraad van bevoegdheden die ruimer zijn dan in de Wet op de ondernemingsraden omschreven. Het ontmoedigen van een niet geïnviteerde overname was geen doelstelling bij het 
aangaan ervan, maar de regeling kan dat effect wel hebben

\section{... algemene voorbeelden; change of control-clausules}

In het algemeen bestaat in de praktijk de zorg over de gevolgen van een niet voorziene overname van de contractspartner. Het kan dan zijn dat de overeenkomst na een dergelijke overname nog wel 'naar de letter' wordt uitgevoerd, maar niet meer 'naar de geest'. In dergelijke gevallen wordt het beter geacht dat de wederpartij van de overnamekandidaat zich uit de contractuele relatie kan terugtrekken. Dit recht verschaft de wederpartij in ieder geval het recht om voortzetting van de overeenkomst, al dan niet op gewijzigde voorwaarden, zelfstandig te overwegen. Dergelijke change of control-bepalingen komen in de praktijk veelvuldig voor.

Zo zal de bank bij kredietovereenkomsten in de regel haar beslissing om geld te lenen mede laten afhangen van de vennootschappelijke structuur van de vennootschap die de lening opneemt. Ook wanneer de bank geen garanties van de aandeelhouder verlangt, is de identiteit van die aandeelhouder een relevant gegeven voor de bank. Indien die identiteit wijzigt, wenst de bank door middel van een change of control-clausule over de vrijheid te beschikken de kredietrelatie op grond van eigen beslissing te beëindigen, dan wel op al dan niet gewijzigde voorwaarden voort te zetten.

Bij het verstrekken van licenties voor het gebruik van intellectuele eigendomsrechten gelden vergelijkbare overwegingen om een dergelijke clausule op te nemen.

Die clausules zijn eveneens van belang voor de partijen die een joint venture overeenkomst aangaan.

De kracht van change of control-clausules, en het afschrikwekkend effect ervan, kunnen aanzienlijk worden versterkt door aan overtreding van de bepaling tevoren vastgestelde boetebetalingen te verbinden. Het overeenkomen daarvan kan geldig geschieden indien het normdoel van de clausule bijdraagt aan de verwezenlijking van het vennootschappelijk belang op het 
moment van overeenkomen ervan. Het feit dat - naast deze doelstelling - ook het afschrikwekkend effect in een later stadium kan optreden, zal in de regel niet aan de geldigheid van de clausule kunnen afdoen.

Deze in de normale gang van zaken overeengekomen clausules kunnen ook verstekelingen blijken, wier onverwachte aanwezigheid kan leiden tot complicaties wanneer een koerswijziging van de onderneming aan de orde is. Deze verstekelingen kunnen al dan niet door het bestuur oogluikend aan boord zijn gelaten juist met het oogmerk dergelijke complicaties.

Het is van belang in te gaan op de bezwaren die ingebracht zouden kunnen worden op het moment van de ontdekking van de verstekeling bij een niet geïnviteerde overnamepoging of bij aandeelhoudersactivisme.

De bieder zou in dat laatste geval kunnen stellen dat de oorzaak van de overeenkomst met de bewuste clausule 'bescherming' is en dat dit ongeoorloofd is gezien de belangen van aandeelhouders bij het kunnen ontvangen van de premie die het kenmerk van een niet geïnviteerde overname is. De bieder zou dan voor het anker van art. 3:40 BW gaan liggen. De kans dat de bieder in deze actie succesvol is, wordt geringer naarmate de doelvennootschap duidelijker kan aantonen dat de oorzaak past bij het verwezenlijken van de commerciële doelstelling van de vennootschap en dat de clausule leidt tot of bijdraagt aan resultaatsverbetering in de normale bedrijfsuitoefening van de onderneming. In de gegeven voorbeelden was dit het geval. Zonder de clausule zou de overeenkomst niet of niet op vergelijkbare gunstige voorwaarden kunnen worden gesloten, en de clausule had tot voorzienbaar gevolg dat de vennootschap en de contractuele wederpartij voordeel genoten als gevolg van het overeenkomen van de clausule.

Een actie tot vernietiging van de overeenkomst lijkt daarom niet kansrijk.

De bieder zou voorts kunnen stellen dat het bestuur haar taak 
niet naar behoren heeft vervuld, en dat ook daardoor de oorzaak van de overeenkomst wordt gekleurd. Ook dit argument zal niet snel tot versterking van de positie van de bieder leiden. Bij het beoordelen van de bestuurlijke takkvervulling geldt een negatieve toets. Het bestuurlijk handelen mag geen onbehoorlijke taakvervulling zijn en de beoordeling daarvan dient marginaal te geschieden. De marginale toetsing geldt ook bij de beoordeling van het 'verstekelingeffect'.

Dit zou wellicht anders zijn wanneer de clausule gegoten blijkt te zijn in een zodanige vorm dat iedere controlewijziging leidt tot activering ervan en dus tot het feitelijk onmogelijk maken van geïnviteerde overnames en gewenste fusies. In een dergelijk geval heeft het bestuur de vennootschap opgezadeld met een clausule die de toekomstige expansie van de onderneming belemmert of anderszins het goede bestaan van de onderneming hindert, en zal sprake zijn van onbehoorlijk bestuur en wellicht ook van een aantastbare overeenkomst. Het gaat dan naar mijn oordeel om op Pandora-constructies gelijkende regelingen en dergelijke regelingen lijken mij aantastbaar.

Het bestuur zal moeten kunnen aantonen dat het aangaan van de overeenkomst waarvan de clausule deel uitmaakt, paste in de normale gang van zaken van de onderneming. Zo zal een clausule die pas is opgenomen nadat sprake is van een dreiging van een niet geïnviteerde overname, aanmerkelijk kritischer dienen te worden beoordeeld dan een overeenkomst die tot stand is gekomen onder omstandigheden waarbij van die dreiging geen sprake was. De vergelijking met de verkoop van LaSalle door ABN Amro dringt zich hierbij op. De Ondernemingskamer oordeelde dat het feit dat ABN Amro in play was, meebracht dat de beleidsvrijheid van het bestuur werd gekwalificeerd. Dit element lijkt ontleend aan de hiervoor besproken Revlondoctrine en is niet met zoveel woorden door de Hoge Raad herzien.

Zo kom ik tot de conclusie dat het verstandig zou zijn dat Nederlandse ondernemingen zich realiseren dat de kracht van de 
klassieke en technische bescherming beperkt is of zelfs geheel dreigt te verdwijnen. Deze ondernemingen zouden zich voorts kunnen realiseren dat in contractuele relaties die in de normale bedrijfsuitoefening worden aangegaan, tevens bepalingen kunnen en mogen worden opgenomen die als verstekeling aan dek komen wanneer sprake is van een niet geïnviteerde overname of aandeelhoudersactivisme. Wanneer deze contractuele bepalingen voldoen aan de geschetste voorwaarden zal het niet eenvoudig zijn de geldigheid ervan aan te tasten en kan het effect ervan zijn dat feitelijke bescherming optreedt ondanks het ontbreken van juridische beschermingsmaatregelen. 

